\title{
Ecological Civilization and Dispute Resolution in the BRI
}

\author{
Peter CORNE \\ Partner, Dorsey \& Whitney, LLP, Shanghai, China; Global Adjunct \\ Professor of Law, New York University, New York, USA; Mediator, Shanghai \\ Commercial Mediation Center, Shanghai, China; Arbitrator, Shanghai, \\ Shenzhen and Hong Kong, China \\ corne.peter@dorsey.com
}

Vivien $\mathrm{ZHU}$

Haiwen \& Partners, Shanghai, China

vivien_zhu199406o6@foxmail.com

\begin{abstract}
One of the main challenges facing China in executing its Belt and Road Initiative is dealing with the complexities arising from its interactions with disparate cultures, ecosystems, societies and their associated laws and local practices. This article argues that intrinsic to the concept of ecological civilization is its incorporation of a broad set of culturally derived norms and customs that represent an inclusive approach to cultural and ecological diversity. The article advocates the adoption of mediation along the Belt and Road as the primary or 'first line' dispute resolution tool, with a third party neutral acting as a mediator. As a 'facilitative' rather than an 'adjudicative' process, mediation under the guidance of a well-trained mediator can steer the parties to the settlement of a dispute related to the environment and natural resources in a way that is consistent with the principles of ecological civilization while respecting the broader concerns of each participant under their respective 'living laws'. The article maintains that as a 'second line' or alternatively 'parallel line' of dispute resolution, arbitration will continue to be critically important for BRI disputes, so measures that will oblige arbitrators to incorporate ecological principles into their deliberations are also recommended.
\end{abstract}




\section{Keywords}

ecological civilization - dispute resolution - mediation - arbitration - Belt and Road Initiative - B RI

One of the main challenges facing China in executing its Belt and Road Initiative (BRI) is dealing with the complexity arising from China's interactions with disparate cultures, ecosystems, societies and their associated laws and local practices. Inherent to the concept of ecological civilization, is its acknowledgment of a broad set of culturally derived norms and customs that represent an inclusive approach to cultural and ecological diversity.

Ecological civilization is derived from the Confucian and Daoist philosophical tenets of respect for nature, equality of human beings with other species, and maintenance of harmony within and between society and nature. ${ }^{1}$ The concept has attracted a great deal of comment, ${ }^{2}$ but there is as yet no agreed legal definition. One straightforward way of defining it is based on extending the idea of sustainable development, long-accepted by China and the international community: 'ecological civilization refers to a society that enshrines as its core aspiration the pursuit of a form of sustainable development that emphasizes the harmonious co-existence of humans with their surrounding ecosystems.' ${ }^{3}$ However, a fuller understanding of the concept involves a consideration of complex historical, political, philosophical and cultural elements, as this article aims to demonstrate.

In emphasizing the maintenance of 'balance' and 'harmony' by drawing upon a broader concept of normative reality than 'law', the principles of ecological civilization could be applied as a conceptual framework for resolving commercial disputes along the BRI that involve environmental issues or have

1 See eg Martin SCHÖNFELD and XIA Chen, 'Daoism and the Project of an Ecological Civilization or Shengtai Wenming 生态文明' Religions, 2019, 10, 630 .

2 See eg Arthur HANSON, 'Ecological Civilization in the People's Republic of China: Values, Action, and Future Needs' ADb East Asia Working Paper Series, No. 21, December 2019; Paul BARRESI, 'The Role of Law and the Rule of Law in China's Quest to Build an Ecological Civilization', Chinese Journal of Environmental Law 1 (2017) 9-36.

3 Definition proposed by a working group (of which Peter CORNE was a part) convened during the Ecological Civilization and Global Environmental Governance International Workshop, Hainan University, 23 October 2019. 
an environmental impact either through a mediation settlement or adjudicative decision. These principles, while primarily derived from Daoist and Confucian tradition, as discussed below, were spelled out in a concrete manner by President XI Jinping in his speech to the 19th National Congress of the Communist Party of China in $2017,{ }^{4}$ summarised as: (i) economic development must be in harmony with nature; (ii) industrial structures and ways of work and life moving forward must help conserve resources and protect the environment; (iii) legal and policy and like frameworks henceforth must facilitate green, low carbon and circular development; and (iv) reducing desertification, afforestation and regeneration of land and water bodies are a priority. Legally specified requirements based on these principles could serve both as a safety valve and a vehicle to evaluate, capture and address any environmental issues that may otherwise be neglected in commercial disputes.

Currently, adjudicative tools such as arbitration and litigation dominate international dispute resolution. Almost universal accession to the New York Convention on Recognition and Enforcement of Foreign Arbitral Awards 5 enabled arbitration to become enforceable in countries around the world. But adjudicative forms of international dispute resolution are limited by both procedure and the limited scope of black-letter applicable law, when applied to cross-border, cross-cultural disputes. The significant expense in terms of resources and time that they entail often can give rise to inequitable results. Their adversarial nature normally precludes the continuation of working relationships, and their 'win-lose' approach creates implementation challenges despite the existence of the New York Convention.

This article advocates the adoption of mediation along the BRI as the primary or 'first line' dispute resolution tool involving a third party neutral. As a 'facilitative' rather than an 'adjudicative' process, mediation under the guidance of an enlightened mediator, who is well-trained in multi-stakeholder environmental dispute settlement techniques, ${ }^{6}$ can encourage the parties by way of a targeted statement at the outset of the mediation. It is argued here that mediation rules could incorporate a pre-commitment of the parties to

4 XI Jinping, 'Secure a Decisive Victory in Building a Moderately Prosperous Society in All Respects and Strive for the Great Success of Socialism with Chinese Characteristics for a New Era' 19th National Congress of the Communist Party of China, October 18, 2017; see primarily 46-48<http://www.xinhuanet.com/english/special/2017-11/o3/c_136725942.htm>.

5 Convention on the Recognition and Enforcement of Foreign Arbitral Awards 33 O UNTS 38 (1958) (hereinafter New York Convention).

6 Such training is available, see eg Mediators Beyond Borders International Training Institute, 'Environmental Conflict Management and Stakeholder Engagement' Course, led by Tom FIUTAK, Bali, October 2019 . 
the concept of ecological civilization to settle the dispute in a way that is consistent with the principles of ecological civilization while respecting the broader concerns of each participant under their respective 'living laws. ${ }^{7}$ The signing of the Singapore Mediation Convention, ${ }^{8}$ with many of the current $5^{2}$ signatories ${ }^{9}$ being BRI countries, provides a mechanism for the enforcement of mediation settlement agreements in ratifying countries, thereby becoming a catalyst for the elevation of mediation to the primary mode of dispute resolution applied along the BRI. In recognition that arbitration will remain a critical dispute resolution tool, this article also explores how ecological civilization concepts might be incorporated into the deliberations of arbitrators as fundamental guiding principles woven into the fabric of their awards.

There are many examples over the brief history of the BRI of Chinese companies struggling in their interactions with host BRI countries that harbour disparate cultures, societies and ecosystems and associated laws and local practices, and which may be in danger of becoming locked into an accelerating circular pattern of misunderstandings. Symptomatic of the challenge of dealing with the cultural divide, there have been several well-documented instances of serious disputes between Chinese companies and local staff ${ }^{10}$ and local communities. ${ }^{11}$ Further evidence of the proliferation of such issues is found in a 2019 Survey Report on Chinese Private Enterprise along the Belt

7 The concept of the 'living law' was coined by Eugen Ehrlich, who opined that living law lies within the inner order of societies consisting of social norms; black letter law is only part of an expanded concept of law, and smooth operation of the society requires positive interaction between black letter law and living law. See Yunyun HAO, 'The Game Between National Law and Living Law in Judicial Trials-Thought on Eugen Ehrlich's Living Law Theory' (2016) 04 TSSF <http://www.cnki.com.cn/Article/CJFDTotal-TSSF201604039 .htm>.

8 United Nations Convention on International Settlement Agreements Resulting from Mediation (hereinafter Singapore Convention, in force 12 September 2019) is an international agreement regarding the recognition of mediated settlements.

9 As of October 2020; see <https://www.singaporeconvention.org/>.

10 For example, the problems encountered by Huajian Group in Ethiopia; see Yongqing SHEN, 'Huajian Group: Dongguan Father of Ethiopian Employees' (Time of Dongguan, 29 December 2019) <http://news.timedg.com/2017-12/29/20638313.shtml>.

11 See issues encountered in the Oriental Industrial Park in Ethiopia in 2016, in Mengmei FU, 'Chinese enterprises' awareness of business along BRI' (2017) 15 World Affairs 67. Also see Baker \& McKenzie, 'BRI Risk Mitigation and Dispute Resolution Options in the Coming Decade' (Asia Legal Business, 13 December, 2019) $<$ https://www 
and Road Initiative issued by the Nationwide Association of Industry and Commerce of China, which reported that $60.9 \%$ of Chinese enterprises in Indonesia, $63.6 \%$ of Chinese enterprises in Kazakhstan and $50 \%$ of Chinese enterprises in Malaysia surveyed relayed that religious, cultural and lifestyle differences between Chinese management and local staff were seriously impacting the operations of their enterprises. ${ }^{12}$

Lack of deference or knowledge of local requirements has led to compliance lapses by Chinese companies such as that seen in Kazakhstan in respect of environmental regulation ${ }^{13}$ and failure to anticipate differences in judicial approaches to generic legal concepts such as force majeure, which has given rise to disruption and friction in business relationships. ${ }^{14}$

\subsection{Ecological Civilization-More than a Catch-Cry}

Intrinsic to the concept of ecological civilization is its acknowledgment of a broad set of culturally derived norms and customs that represent an inclusive approach to cultural and ecological diversity. Such norms and customs are derived from the Confucian and Daoist philosophical tenets of respect for nature, equality of human beings with other species, and maintenance of harmony within and between society and nature. These two founding pillars of traditional Chinese philosophy have focused on the relationship between humans and the environment for thousands of years, having been derived from the reliance of the ancient Chinese on farming and their respect for the rules of nature. ${ }^{15}$

Mediation as a form of dispute resolution in China can be seen by an examination of its constituent Chinese characters to be imbued with these philosophical tenets. The Chinese term for mediation '调解' (tiaojie) consists of the characters '调' (harmonising) and '解' (solving). The combination

.legalbusinessonline.com/news/bri-risk-mitigation-and-dispute-resolution-options -coming-decade-december-issue-brought-you >

12 Ruohan WANG, 'Focus-The New Report is All Clear on the Status Quo of Chinese Private Enterprises involved in BRI!' (Sohu News, 25 November 2019) <https://www.sohu .com/a/356775533_731021>.

13 In 2019, see environmental non-compliance event of Chinese-funded CNPC-ADM Co. Ltd., located in Kyzylorda of Kazakhstan. See Muhtar MULAT, 'Chinese Oil Company Is Punished For Violating Kazakhstan's Environmental Regulations' (Kazinform, 15 January 2019) <https://www.inform.kz/cn/article_a3488079>.

14 See Stephen STAPCZYNSKI, 'CNOOC refuses LNG cargoes, declaring force majeure over coronavirus' (World Oil, 6 February 2020) <https://www.worldoil.com/news/2020/2/6/ cnooc-refuses-lng-cargoes-declaring-force-majeure-over-coronavirus $>$.

15 Hua YANG, 'Entering Ecological Civilization in Ancient Times' (2012) 7 GD $<$ http:// epaper.gmw.cn/gmrb/html/2012-04/o4/nw.D110ooogmrb_20120404_3-07.htm>. 
of the two characters could be translated as 'solving [a dispute] through harmonising.'.6 And as illustrated by the Daoist and Confucian view of the inseparability of humans and nature, maintenance of 'harmony'-a concept intrinsic to mediation - is not limited to merely maintenance of harmony within society—it also includes maintenance of society's harmonious interaction with nature.

The following briefly canvasses the philosophical tenets mentioned above in an attempt to show their relevance to the concept of ecological civilization and the need to seek harmony between humans and nature.

The most well-known tenet of Confucian thought in terms of the relationship between human beings and nature is '天人合一', meaning that 'nature and humans are integrated and inseparable', and as such, social order must develop in harmony with the natural ecological order. Confucius asserts that " 天何言哉。四时行焉, 百物生焉。天何言哉, interpreted as 'the cycle of the four seasons and the growth of all creatures have their own rules, which must not be subject to interference by humans. ${ }^{\prime 7}$ Xunzi, another representative Confucian scholar, is well-known for advocating the following ecological philosophy: ‘天行有常, 不为尧存, 不为桀亡': 'nature develops according to its own routines and rules, the existence or extinction of which is not subject to the whims of humankind'; '道而不淢则天不能祸: ' 'one must follow the rules of nature if nature is not to bring disaster upon human beings'; ‘开源节流': 'one can exploit water resources only so long as one is also mindful of preserving such resources and their quality'; and “王者之法, 等赋, 政事, 财万物, 所以 养万民也': 'the emperor is responsible for managing citizens and natural resources so that such resources will continue to sustain society'.18

Similarly, Daoism explores the relationship between nature and humans and has an ecologically philosophical basis. 'Dao de jing', the Virtue of the Dao, was a set of revolutionary ideas that underpins the concept of ecological civilization. It advocates that humankind should live in harmony with and obey the laws of nature. Daoism urges its followers to protect the environment, conserve natural resources, maintain ecological balance, and for that purpose, adopt a simple and austere lifestyle.

\footnotetext{
16 Knut B PISSLER: “Mediation in China:Threat to the Rule of Law?", in Mediation:Principles and Regulation in Comparative Perspective, Klaus J HOPT and Felix STEFFEK, Oxford Scholarship online, 2013 .

17 Junjie PAN, Lu YU, 'An Investigation into Ecological Civilization in Early Confucianism' (2015)1 FL <http://mall.cnki.net/magazine/Article/QXZZ201501015.htm>.

18 Xiuyu ZHANG, Yuan LI, Xiaochun PENG, Zhencheng XU, Fantang ZENG, "Ecological Philosophy and Ecological Civilization Construction Theory of Xunzi” (2014) 2 Ecoc. <http://www.cecrpa.org.cn/stwh/sh/2016o3/t20160331_637914.shtml>.
} 
Representative ecological ideas of Daoism include '以道观之, 物无贵贱”: 'all beings on the earth are equal and no single being is nobler than another'; ‘ 万物归焉而不为主': 'humankind is equal to all other species as humankind is a part, and not master, of nature', ‘法地、地法天, 天法道, 道法自然: ‘as humankind is an inseparable part of nature, it should follow nature's rules and develop in harmony with nature, thereby forging a dynamic balance with the natural world' ${ }^{19}$ Hence the Daoist view of the world would consider the current climate crisis as a natural consequence of modern society not functioning in accordance with nature's flow, or 'going against the Dao'. ${ }^{20}$

It should be noted that ecological civilization and the Daoist/Confucian philosophical underpinning of harmonious interaction with surrounding ecosystems is in stark contrast with the corresponding Western philosophical thinking about nature extending as far back as the teachings of Aristotle. The Judeo-Christian tradition set a foundation for Western civilization to conceive of humankind as having been created separate and superior to nature, for the purpose of subduing and dominating nature for its own ends. ${ }^{21}$ The Greek tradition also substantiated the man/nature duality, with humankind given a dominant place in a well-planned hierarchical world. ${ }^{22}$ Only European Romanticism and American Transcendentalism recognized the intrinsic value and sublimity of nature, but could not break free of the notion of mankind's separateness from nature. ${ }^{23}$ That being said, the United Nation's Sustainable Development Goals (SDGs) seem to have forged a certain commonality of purpose with ecological civilization in its acknowledgment of the necessity of the creation of a relationship of harmony with nature (see eg Goal 12.8). The theme of the 15th Conference of the Parties to the Convention on Biological Diversity, now set for 2021, appears to embody this commonality of purpose, with the theme 'Ecological Civilization: Building a Shared Future for All Life on Earth.' ${ }^{24}$

19 Zongxian LI, 'The Unity Of Human-being and Nature-Ecological Wisdom Of Taoism' (Ecological Civilization of China, 11 December 2014) <http://www.cecrpa.org.cn/stwh/ sh/201412/t20141211_637899.shtml>.

20 Martin SCHÖNFELD and Xia CHEN (n 1$) 7$.

21 Alex GEISINGER, 'Sustainable Development and the Domination of Nature: Spreading the Seed of the Western Ideology of Nature' [1999] BCEAL Rev vol 27, Issue 1. 43-74, 50. Available at: $\langle$ http://works.bepress.com/alex_geisinger/17/ >

Lynley TULLOCH, 'Is Emile in the Garden of Eden? Western Ideologies of Nature', Abstract Policy Futures in Education 2015, Vol. 13(1) 20-41, 26, <sagepub.co.uk/journals Permissions.nav>.

23 GEISINGER (n 21) 68-73.

24 China is set to host the $15^{\text {th }}$ Conference of the Parties to the Convention on Biological Diversity (СвD СOP15). See <https://www.planeta.com/cbdcop15/>; see also Lingyu KONG, 'Can China take the Lead in the UN Biodiversity Process?' China 


\section{Bringing the Tenets of Eco-Civilization into the Realm of Dispute Resolution}

Chinese traditional philosophy has had an important role in shaping the mindsets, behaviour and social interaction of the Chinese people. ${ }^{25}$ Ancient dispute resolution mechanisms in China following the Qin and Han Dynasties broadly applied the values of Confucianism to resolve disputes, including fairness (义), sensibility (人情) and etiquette (礼). ${ }^{26}$ Even in modern Chinese society, the guiding principle of harmony and not upsetting social order still infiltrates dispute resolution systems. ${ }^{27}$ Achieving harmony in China in the context of maintaining societal relations through the upholding of 'face' (面子) is still valued more highly than the pursuit of face-losing 'winner takes all' approaches, ${ }^{28}$ and this could be said to be the favoured approach in Asian cultures generally. Parties more readily accept a resolution based on the 'living law' due to its closeness to practice in everyday life. ${ }^{29}$

'Living law' is said to lie within the inner order of societies, and is a largely unwritten set of customary, religious, business and ethical rules that takes many different forms. ${ }^{30}$ While it is not to be applied in priority to positivist law, it could rather serve as a safety net to capture any environmental concerns that might be otherwise ignored in commercial disputes. Ecological civilization is an expression of such living law, and its resonance across borders has the potential to achieve traction as demonstrated by nearly global recognition of similar concepts in a number of different cultures. As KUHN has stated: 'Ecological Civilization ... seeks to complement the three core dimensions of the concept of sustainable development - the environmental, the economic, and the social dimensions - with specific features of Chinese political civilization, aspects of Chinese governance, and core elements of the Chinese sustainable

Dialogue, 17 September, 2020, <chinadialogue.net/en/nature/csn-china-take-the-lead -in-the-un-biodiversity-process/>.

25 Shaobin TU, He JIANG, 'Preliminary Analysis on Confucianism as Living Law' (2010) O5 FXPL <http://xuewen.cnki.net/cjfd-fxpl201005021.html >.

26 ibid.

27 'Consideration of social effects has led (PRC) judges to sometimes care more about the public's perception of justice, rather than the parties' perception of justice in a particular case': Guodong DU, How Chinese Judges Think China Justice Observer, 4 January 2019 $<$ www.chinajusticeobserver.com $>$.

28 Hong LIAN, 'Confucian Concept of Harmony And Chinese Traditional Mediation System' (2005) O2 CCLG <http://www.cnki.com.cn/Article/CJFDTotal-CCLG200502029.htm>.

$29 \mathrm{HAO}\left(\mathrm{n}_{7}\right)$.

$30 \quad$ Yuan ZHOU, 'On The Theory of Living Law' (2008) o4 SQJY.

<http://www.cnki.com.cn/Article/CJFDTotal-SQJY200804153.htm>. 
economic development agenda'. ${ }^{31}$ For example, from a Buddhist perspective, sustainability concerns ecology, economy and evolvability, which means the potential for human beings to live in harmony with the environment. ${ }^{32}$ Hindu religious texts emphasize the oneness and unity of oneself with every other being on the planet. ${ }^{33}$ Further, the Qur'an contains many references to water and other vital natural resources, laying down clear guidelines for their conservation and equitable distribution. ${ }^{34}$

In emphasizing the maintenance of 'balance' and 'harmony' by drawing upon a broader concept of normative reality than black letter law, the principles of ecological civilization could be applied as a conceptual framework for resolving disputes between private actors along the BRI that overcomes the rigidity of legal regimes and their relative inability ${ }^{35}$ to take into account on the one hand, 'living law' practices, and on the other, the maintenance of ecological balance, in contriving solutions to disputes. Notably, in mediation, the applicable rules and even the parties' arguments are not limited to black letter law, and living law (which includes social norms and ethical rules) could also play an important role. In cross-border arbitration, the tribunal of certain arbitral institutions, eg China International Economic and Trade Arbitration Commission, in the absence of agreement between the parties, enjoys the discretion to apply any law or rule it deems appropriate. ${ }^{36}$

\section{4}

\section{Entrenching and Clarifying the Tenets of Eco-Civilization}

It is argued here that, if they are to maintain international credibility, Chinese enterprises cannot afford to have different compliance standards in China to that which they apply along the Belt and Road, where local environmental law may not be at the same level as that of China in quality or implementation. So how can the concept of 'ecological civilization' be applied so that it achieves traction as a compulsory reference point in dispute settlement along the BRI?

31 Berthold KUHN, 'Ecological Civilization in China' (DOC Research Institute, 26 August 2019) $<$ https://doc-research.org/2019/o8/ecological-civilisation-china-berthold/>.

32 Jan SERVAES, Sustainable Development Goals in the Asian Context (Springer 2017) 4.

33 Anthony LE DUC, 'Environmentalism and Environmental Sustainability in Asia', ibid 61.

34 R FOLTZ, 'Ecology in Islam', in ALC RUNHELOV and L OVIEDO (eds), Encyclopedia of Sciences and Religions. Springer, Dordrecht.

35 In some commercial contracts, there are no environmental compliance provisions, so a case concerning mere breach of contract may not address the environmental impact of such an event.

36 See Article $49(2)$ of Arbitration Rules of China International Economic and Trade Arbitration Commission 2015 . 
Is there something that China can do to entrench this on a bilateral or multilateral level?

Currently there are no legally enforceable instruments in place that compel Chinese enterprises to incorporate sustainability safeguards into their investments along the BRI. Only non-binding guidelines and pronouncements issued by the Ministry of Commerce, the National Development and Reform Commission (NDRC), and the predecessor of the Ministry of Ecology and Environment (MEE), have begun to address this gap. ${ }^{37}$ The Administrative Measures for Chinese Enterprises Investing Overseas, issued by the NDRC on 20 November 2017, coming into effect on 1 March 2018, while possessing binding legal force in respect of Chinese companies, only weakly reference environmental protection in Article $41 .^{38}$ If a company is required to demonstrate that it has to put in place the required strict environmental warranties, indemnities and impact assessment report commitments as a pre-condition for NDRC foreign investment approval, it is argued that they would be more likely to take note. If they did not take note, those Chinese companies would not be granted approval for their proposed outbound investment by their supervisory authorities.

China could do more to build environmental commitments into the various B RI Memoranda of Understanding (MOU) with different countries, which would then in turn become reference points for lawyers, mediators and arbitrators alike in their management, or deliberations in respect of, disputes involving private actors and States. To date such Mous have not followed a consistent pattern, and it is only in the $2019 \mathrm{MOU}$ with Italy that we see a clear commitment articulated. ${ }^{39}$ Section 6, entitled 'Green Development Cooperation' and paragraph II, 'Areas of Cooperation', provides commitments to supporting low carbon and circular economy development, enhancing cooperation and

37 See for example, Article 28 of the Code of Conduct of Private Enterprises' Overseas Investment Operation, issued on 6 December 2017 by the NDRC, Ministry of Commerce, People's Bank of China, Ministry of Foreign Affairs, and the National Federation of Industry and Commerce, see guidelines listed in the appendix in Ben BOER, 'Greening China's Belt and Road: Challenges for Environmental Law', (Sydney Law School Research Paper, July 16 2019) <https://ssrn.com/abstract=3420544>.

38 Article 41 provides that 'investors should innovate their method of outbound investing, ... respect local public order and good customs, perform their necessary social responsibilities, and pay attention to the protection of ecological environment and create a good image of Chinese investors'.

Ben BOER (n 37) 14. 
promoting the implementation of the Paris Agreement, whilst participating in UNEP-sponsored green BRI initiatives. ${ }^{40}$

Similar wording and expressions could be adopted to the various BRI Memoranda of Understanding with different countries.

Further, in the context of green financing, which includes loans and the issuance of 'green' corporate bonds, more Chinese Banks can commit to requiring their Chinese customers along the BRI to 'Triple Bottom Line' (твL) environmental principles, as well as to a regular verification process, as a precondition as reflected in the Asian Infrastructure Investment Bank's Environmental and Social Framework (ESF). ${ }^{41}$ The 'Triple Bottom Line', involving environmental regeneration has evolved into the development of a Scorecard to assess any bank's activities based on the Principles of Sustainable Banking. ${ }^{42}$ Therefore, rather than downplaying or trivializing environmental protection in preference to economic development, the Triple Bottom Line is helping to steer banks' businesses towards sustainable lending and in turn restrain Chinese investors from engaging in environmental misconduct, at least when under bank scrutiny.

China could undertake to harmonize environmental laws, standards and protocols under the rubric of ecological civilization by building a body of uniformly applicable rules through multi-lateral agreements. As Simonov cogently argues, ${ }^{43}$ these could be fast-tracked by using existing international instruments as models, such as United Nations Economic Commission for Europe (UNECE) Conventions, ${ }^{44}$ which could serve as a ready source of tested environmental

40 Memorandum of Understanding Between the Government of the Italian Republic and the Government of the People's Republic of China on Cooperation within the Framework of the Silk Road Economic Belt and the 21st Century Maritime Silk Road Initiative <https:// www.affaritaliani.it/politica/geopolitica/belt-and-road-here-is-the-italy-and-china -memorandum-of-understanding-593165.html>.

41 Malik R DAHLIN, 'Dispute Regulation in the Institutional Development of the Asian Infrastructure Investment Bank: Establishing the Normative Legal Implications of the Belt and Road Initiative', Chapter 9 of International Organizations and Promotion of Effective Dispute Resolution, in Peter QUALE and Xuan GAO eds, AIIB Yearbook of International Law, Brill 2019 <http://www.jstor.org/stable.10.1163/.ctvrxk3sj.11> 127, in respect of the three criteria which it considers before financing, two of which are arguably environmental in nature.

42 Global Alliance for Banking on Values, Assessing Banks: Delivering a Triple Bottom Line in the Real Economy, available at <http://capitalinstitute.org/wp-content/uploads/2016/ o1/201601_scorecard_overview-1.pdf $>$.

43 Eugene SIMONOV, 'Would Ecological Civilization Take the Silk Road?', Rivers Without Boundaries, 27 March, 2016 <http://www.transrivers.org/2016/1650/>.

44 Examples of such conventions are the Convention on the Protection and Use of Transboundary Watercourses and International Lakes 1936 UNTS 269 (1992); Convention on 
safeguard mechanisms. Already many pan-Eurasian initiatives exist that are planning mega-projects, co-founding investment banks, and building energy networks, as Simonov states. 45

Should the concept of ecological civilization and associated standards become enshrined in commitments at a multi-lateral level, in BITs and other bilateral treaties, and become woven into contract templates that parties are by and large compelled to follow by way of requirements imposed by financiers (to which they have in turn also been bound to follow) or by authoritative bodies such as the International Federation of Consulting Engineers, they will become a reference point from the perspectives compliance and dispute resolution, that parties will no longer be able to ignore. One would expect in due course to find reference to standards associated with ecological civilization in compliance programs and associated training modules, as well as in whistleblowing protocols. So, over time. commercial behavioural patterns along the BRI should fall in line with ecological civilization principles appearing in the form of identifiable and concrete environmental standards enshrined in the Mous and multi-lateral agreements. Apart from the likely strong influence of these cross-border agreements, the risk of losing bank financing due to non-compliance with environmental requirements should compel stakeholders to take the necessary precautionary measures.

\section{Mediation and Arbitration as Part of an Accountability System Based on Ecological Civilization and the SDGs}

Mediation and arbitration, as dispute resolution tools, are very distinctive and perform quite different roles. Mediation is primarily a process that is, in its least intrusive form, a facilitative process by which one or several ${ }^{46}$ skilled neutral and impartial third party mediators employ a variety of techniques to promote mutual understanding between the parties and to encourage them to

Environmental Impact Assessment in a Transboundary Context (Espoo) 1989 UNTS 309 (1991); Protocol on Strategic Environmental Assessment (Kiev) 2685 UNTS 140 (2003); Convention on Access to Information, Public Participation in Decision-making and Access to Justice in Environmental Matters 2161 UnTs6 447 (1998); Convention on the Transboundary Effects of Industrial Accidents 2105 UNTS 457; and the Convention on Long-range Transboundary Air Pollution 1302 UNTS 217 (1979). ibid.

46 Dual mediator mediation, recently launched by the SCMC in conjunction with the European Union Intellectual Property Office, involves the appointment of two mediators with native language and cultural skills in the respective languages and regions of the disputants. 
resolve their dispute. The two main forms of mediation are 'facilitative mediation', where the mediator tries to ensure that the parties reach agreement without suggesting solutions, and 'evaluative mediation', where the mediator is authorized by the parties to suggest solutions to them. Mediation is voluntary and confidential, and the parties have absolute control over the outcome.

Arbitration, on the other hand is, in effect, a confidential and impartial private court in which an arbitrator or a panel of arbitrators, in addition to exercising control over the process, have the authority to make a final determination in the form of an 'award' in respect of the dispute. (The arbitrator is at liberty to suggest that the parties attempt to mediate a settlement, but if mediation is not successful, the arbitrator can make an award in any case.) The main difference with mediation is that the parties to an arbitration abrogate all control over the outcome to the arbitrators.

Currently, adjudicative tools such as arbitration and litigation dominate international dispute resolution. According to ICC Dispute Resolution 2018 Statistics, in 2018, 842 new arbitral cases were registered with the Secretariat, thus setting a new record for the International Chamber of Commerce (ICC). In contrast, in 2018, the Centre registered only 37 new filings under the ICC Mediation Rules (which nevertheless was still a new record for the Centre). The year 2018 also set a record for the number of parties involved in ICC mediation cases, with 100 parties from 36 countries and independent territories. ${ }^{47}$

The signing of the Singapore Convention ${ }^{48}$ in 2019 has ushered in an era where mediation has, for the first time, assumed the status as a legitimate and enforceable dispute resolution tool in the area of international commerce. With this comes the opportunity for China to apply modern techniques that it has learned from the rapid development of domestic court-related mediation, while incorporating the overriding principles of ecological civilization. This is especially so because such principles are inclusive enough to incorporate the SDG $\mathrm{s}^{49}$ and local concerns derived from the 'living law', to initiate a cross-border dispute resolution approach that seeks to minimize potential environmental impact. As a 'facilitative' or 'evaluative' process rather than an 'adjudicative' process, mediation under the guidance of an enlightened mediator can encourage the parties to settle in a way that is consistent with the principles of ecological civilization while respecting the broader concerns of

47 International Chamber of Commerce, ICC Dispute Resolution 2018 Statistics (ICC Publication No.: 898E) 8, 17 .

48 Singapore Convention on Mediation ( $\mathrm{n}_{7}$ ).

49 At the Third Plenary Section of the 18th Central Committee in 2013, President XI Jinping stressed the reconciliation of contradictions between economic development and the environment. 
each participant under their respective 'living laws' on the presumption that such principles have already been built into the dispute resolution regime along the Belt and Road.

Mediation as a dispute resolution technique adds considerably more value than a purely adjudicative process, as it treats social norms as valid components of dispute resolution, of which the ideas of environmental protection and sustainability can be a part, as introduced above. ${ }^{50}$ In the cross-cultural context, especially with what BIRCH describes as 'high context' (where parties focus on surrounding circumstances when interpreting data) as opposed to 'low context' cultures (where parties focus on what they see as objective facts while placing little focus on surrounding circumstances), ${ }^{51}$ mediation is especially effective as conflicts often arise as a result of misconceptions, miscommunications and misunderstandings. ${ }^{52}$ As BELHORNE points out, where disputants have reciprocal relationships and share common goals, they will be more attuned to optimal social norms, with time constraints and informality enriching such outcomes. Mediation forums that serve the needs of such disputants, with the mediator working assiduously to restore a level of trust between the parties, are more likely to produce fair and creative outcomes and that take into account environmental implications, and which may deviate from adjudicative outcomes. ${ }^{53}$ Therefore to the extent that it has yet to be institutionalized in international conventions or required under contracts applicable to the dispute at hand, the principles of ecological civilization can still shape settlement agreements where they are recognized by the parties as reflective of the applicable 'living law' under the guidance of a mediator.

There are currently a number of institutional options for the utilization of international mediation to resolve BRI disputes. As mediation is voluntary, the choice will ultimately depend on the election of the parties. Choices range

5O Scott R. BELHORNE, 'Settling Beyond the Shadow of the Law: How Mediation Can Make the Most of Social Norms', Ohio State Journal on Dispute Resolution, Vol. 20: 3, 2005, at p988. See Section 3 above.

51 Elizabeth BIRCH, "Practical and Cultural Aspects of International Mediation", Yearbook on International Arbitration, 5, 2017, 215-234, at p 229-232. The following cultures are identified in a continuum of high-context to low-context, in order: Japanese, Chinese, Arab, Greek, Mexican, Spanish, Italian, French, French Canadian, English, English Canadian, American, Scandinavian, German, and German Swiss.

$5^{2}$ Guiguo WANG, Xiaoli HE, "Mediation and International Investment: A Chinese Perspective", (2012) 65 Me L Rev 215, at p236. Also see Mediators Beyond Borders, Case Studies Demonstrating the Use of Mediation, Consensus Building and Collaborative Problem Solving in Resolving Environmental and Climate-related Conflicts, October 2019. (Handout at Biennial Conference in Bali). 
from the China International Commercial Court one stop-shop 'multi-door courthouse ${ }^{\prime 54}$ platform that allows disputants to choose their preferred dispute resolution device from a suite of models and associated institutions, the International Chamber of Commerce with its dedicated International Center for ADR and its Belt and Road Commission, the mediation platform set up by Singapore Mediation Center and the China Council for the Promotion of International Trade, the various iterations of Shanghai Commercial Mediation Centre partnerships in mediation, including the co-mediation models with the European Union Intellectual Property Office and Joint Arbitration and Mediation Services, the Environmental Rules under the Permanent Court of Arbitration, ${ }^{55}$ and the to-be-launched mediation rules under the Convention on the Settlement of Investment Disputes (ICSID) ${ }^{56}$

With the exception of the Permanent Court of Arbitration, none of these institutions have a particular environmental or sustainability orientation. To incorporate carefully specified principles of ecological civilization in the mediation process, this article suggests that mediation bodies can adopt a number of measures. The first is for such bodies to make reference to ecological civilization (which could be given more specificity by linkage to particular parts of the Sustainable Development Goals) within their institutional rules as a guide. One way of doing this is to incorporate ecological civilization principles into the preface of institutional rules as a first step and then flesh out such principles in individual clauses. The ecological civilization concept, as discussed above, has a second facet, which is the emphasis of harmony between the stakeholders. In addition, much like the Permanent Court of Arbitration (PCA) has provided in Article 7 of its Rules for Conciliation of Disputes in Relation to the Environment or Natural Resources (2002), ${ }^{57}$ parties should be given the opportunity to elect what this article has referred to as 'evaluative mediation' under which the mediator (referred to in the PCA rules as a conciliator) can provide proposals for a solution to the parties that will be environmentally

54 Frank EA SANDER, 'Varieties of Dispute Processing', in The Pound Conference:Perspectives on Justice in the Future, 4 (Leo A LEVIN and Russel R WHEELER eds, 1979).

55 See PCA Optional Rules for Arbitration of Disputes Relating to the Environment and/ or Natural Resources, adopted in 2011; PCA Optional Rules for Conciliation of Disputes Relating to the Environment and/or Natural Resources were adopted in $2002<$ https://pca -cpa.org/en/services/arbitration-services/environmental-dispute-resolution/>.

56 ICSID has circulated a number of iterations of new Conciliation Rules: Proposals For Amendment of the ICSID Rules, February 2020 Working Paper \# $4<$ https://icsid.worldbank .org/news-and-events/news-releases/icsid-publishes-fourth-working-paper-rule -amendments>.

57 Permanent Court of Arbitration Environmental Dispute Resolution $<$ https://pca-cpa.org/ en/services/arbitration-services/environmental-dispute-resolution/>. 
sustainable. ${ }^{58}$ The commitment to help the parties find such solutions can be introduced at the point of the election for mediation by its inclusion in a 'mediation agreement' between the parties, and in the context of the mediators' agreement to appointment by its inclusion in a 'mediator's statement'. Such safeguards would help to ensure, as Tom FIUTAK of the University of Minnesota has so eloquently advocated, that the 'environment' never fails to occupy an 'extra chair' at the mediation. ${ }^{59}$

\section{$6 \quad$ Arbitration and Ecological Civilization}

Arbitration will remain very important as a dispute resolution tool either under a 'cascading model' where mediation is unsuccessful or, increasingly, under a parallel model in conjunction with mediation. Arbitration could be moulded to incorporate ecological civilization principles into the deliberations of arbitrators. Due to the inherent limitations and defects in laws and regulations, whether international or domestic, soft law is gradually emerging to even become a source of applicable rules in arbitration. ${ }^{60}$ There is no reason why the principles embodied in ecological civilization, as legitimate soft law, ${ }^{61}$ could not also become a reference point for arbitrators in their determination of arbitral awards.

Such 'soft' influences have started to make themselves apparent in several investment arbitral awards in applying bilateral/multilateral investment treaties, which are a convenient reference point. For example, in Methanexv. United States, a tribunal recognized the host states' right to take measures to protect its water resources, which involved the expropriation of the investor's project. ${ }^{62}$ Further, in Glaims Gold Ltd v. United States of America, the tribunal confirmed the enterprise's violation of mining requirements on backfilling and validated

$5^{8} \quad$ Article 7 provides that 'The conciliator will make proposals to preserve the respective rights of the parties, and to prevent and/or mitigate serious harm to the environment falling within the subject-matter of the dispute.'

59 FIUTAK (n 2).

6o Representative soft law that has been applied in international commercial arbitration includes procedural rules and substantive rules. See De LIU, 'Value and Application of Soft Law in International Arbitration' (2018) 33 FZSL <http://mall.cnki.net/magazine/ Article/FZSL201833004.htm>.

61 It has long been a trend that the idea of sustainability and environmental protection drive the behaviours of market actors and recently this has become increasingly recognized by arbitral tribunals in precedents.

62 Methanexv. United States [2005] Ad Hoc Tribunal (UnCITRAL) Final Award on Jurisdiction and Merits, [2005] 44 ILM 1345. 
the host state's administrative action in response. ${ }^{63}$ In Maffezini v. Spain, the tribunal acknowledged Spain's expropriation of the investor's investment based on an environmental infringement of environmental standards. ${ }^{64}$

Thus the challenge with arbitration, and particularly investment arbitration, is to integrate principles derived from the concept of ecological civilization into the criteria that tribunals use to analyse cases in the form of black-letter law or soft law, namely - the legality of the state action, whether such action was taken for a good cause, and whether the action was proportional to the threat posed by the actions of the investor to citizens. ${ }^{65}$

\section{Conclusion}

Ecological civilization, while it is drawn from ancient of Chinese teachings and traditions, shares many of the same underlying concepts embraced by other culturally and religion-based traditions along the BRI. Intrinsic to such philosophies are principles of maintaining harmony within society and harmonious coexistence with nature. Under the watchful eyes of skilled culturally and environmentally aware mediators, disputes can be handled in such a way that cultural and ecological factors can be given due attention in the formulation of settlement solutions that would be difficult to achieve within the strict confines of traditional adjudicative dispute resolution models. With the coming into force of the Singapore Mediation Convention, ${ }^{66}$ mediation deserves to become the first line of dispute resolution along the BRI, either in parallel or sequentially with international arbitration. The opportunity for disputants to exercise control over their solutions and their willingness to embrace the need for sustainability in the process of formulating such settlements should lead to higher and more expeditious resolution rates, greater disputant satisfaction, a higher rate of disputant participation, and ultimately, better environmental outcomes in BRI disputes.

63 Glamis Gold Ltd v. United States [20o9] Ad Hoc Tribunal (Uncitral) Award, [2009] IIC 38 o.

64 Emilio Agustín Maffezini v. Kingdom of Spain [200o] ICSID Case No. ARB/97/7.

65 Sun LIU, 'Legal Conflicts And Coordination Between International Investment And Environmental Protection' (2006) o6 XDFX <http://www.cnki.com.cn/Article/CJFDTOTAL -XDFX2006o6oo3.htm>.

66 Singapore Mediation Convention (n 8). 